\title{
The Role of Time Perspective, Motivation, Attitude, and Preparation in Educational Choice and Study Progress
}

\author{
Jeany Slijper, ${ }^{1}$ E. Saskia Kunnen, ${ }^{2}$ Jeroen Onstenk, ${ }^{3}$ and Paul van Geert ${ }^{2}$ \\ ${ }^{1}$ Inholland University of Applied Sciences and University of Groningen Faculty of Behavioural and Social Sciences, \\ Groningen, Netherlands \\ ${ }^{2}$ University of Groningen Faculty of Behavioural and Social Sciences, Groningen, Netherlands \\ ${ }^{3}$ Inholland University of Applied Sciences, Hoofddorp, Netherlands
}

Correspondence should be addressed to Jeany Slijper; jeany.vanbeelen@inholland.nl

Received 6 April 2016; Accepted 9 October 2016

Academic Editor: Eddie Denessen

Copyright (C) 2016 Jeany Slijper et al. This is an open access article distributed under the Creative Commons Attribution License, which permits unrestricted use, distribution, and reproduction in any medium, provided the original work is properly cited.

The present study examined the relation between study progress in the first year of education and different aspects of the process of study choice of 89 students of higher professional education. This study consists of three parts. Firstly, we explored which concepts are important in open interviews concerning choice of study and study progress. Secondly, we examined the relations between future time perspective and motivation on the one hand and study success on the other hand. Students who focus on the here and now generally continued their studies while students focusing on the future and the ulterior profession, presenting an extended future time perspective, drop out more frequently. Intrinsic motivation is strongly related to positive study progress, and extrinsic controlled motivation is strongly related to dropout. Extrinsic autonomous motivation is in between. Furthermore, students' attitudes towards their future studies were examined in relation to their study progress. The results show that students with an attitude characterized by doubt have the highest risk to drop out. Finally, comparing different orientation programs, we show that students who prepare themselves more intensively before making their choice show less dropout.

\section{Introduction}

Daily practice shows that choosing a higher professional education is not easy for secondary school students. Universities offer try-out classes, open days, and summer schools to help prospective students to make a good choice. The main focus of these activities is to enable students to start their education with more realistic expectations. However, despite these efforts, dropout in the first year of higher education is very high $[1,2]$. The main aim of this study is to gain insight into the process of making an educational choice. We examined the higher education choice process from an individual developmental perspective. In this study we examined the relation between study results in the first year and different aspects that are relevant for this process for students studying law or Social Legal Services in higher professional education. In our study we interviewed students three times before and during the first year of their studies about the process of their choice of studies. The concepts we addressed in this study were chosen because they emerged in the interviews: the students mentioned them spontaneously when talking about the process of their choice of studies. In this study we used mixed methods. In the first part of this study we approached these topics in an explorative way in order to get an indepth overview of the factors that play a role in this choice process and the subsequent progress during the education. We investigated topics that were frequently reported in the interviews as an explorative question, based on the principles of Grounded Theory [3]. In the second part, we made a quantitative analysis of the concepts found to be relevant, on the basis of what students reported in the interviews. After these quantitative results we gave examples of interview quotes, underlying the quantitative results in a qualitative way. In the third and last part of this study, we examined one specific part of the educational choice process: preparing programs and orientation activities, especially their role for study success. In short: we explored the relation between educational success in the first year of the study and time 
perspective, motivation, and attitude towards the studies and intensity of preparation before making a choice.

\section{Preparatory Explorative-Qualitative Study}

\section{Research Questions}

(1) Which topics emerged frequently in the interviews?

(2) Is it possible to assign classifications for these issues that students reported spontaneously?

\subsection{Method}

2.1.1. Participants. The participants in this study were 89 students of the Inholland University of Applied Sciences (higher professional education), from the studies of law and Social Legal Services. The age range was between 17 and 25 years. The participants were randomly selected from a group of 300 students, and the group consisted of 24 men and 65 women. This ratio is representative for the students in the studies of law and Social Legal Services. During an information session two months before the start of the study year, nearly 100 participants were asked to participate.

2.1.2. Instruments. For this study we used the half-open interviews that were administered as part of the Groningen Identity Development Scale, the GIDS [4]. We recorded all interviews. The GIDS consists of a semistructured interview, organized per domain, and questionnaires measuring the commitment, the strength of commitment, and the level of exploration in different domains that are personally relevant for adolescents. In this study we only used the interview data of the domain education and career and not the identity questionnaires and outcomes of the GIDS [4], explaining developmental changes (this paper is part of an overarching Ph.D. study into the processes behind educational choice and educational success of higher professional education students.). During the interviews, open questions were used to stimulate the participants to talk about their career choice. We asked questions such as the following: "With regard to this study, what is really important for you?"; "Did you talk with others about your study choice?"; and "Do you have ideas for the future concerning this study?"; in addition to the open interview, specific questions were asked with regard to the type of preparation that was followed and the educational career prior to the career choice.

2.1.3. Procedure. Over a time period of one year, a comparable half-open interview was administered three times with six months in between. The first interview was shortly before the student started the chosen education, and the last interview was after the end of the first year of education. The participants were interviewed by the first author, in a quiet room. Each interview lasted about 20 minutes. Interviews were administered three times. The interview data were coded and analyzed step by step according to the Grounded Theory approach [3]. The interviews were transcribed and relevant parts were indicated and labelled by using the software package MAXQDA. In the first steps of this analysis of the interviews we explored which topics were mentioned frequently.

2.2. Results. Firstly, we observed that almost all students spontaneously talked about their future. Their discussions of the motives to choose this study referred to different time perspectives. By time perspective we mean the time-span of the perception of the student. They either focused on the present and proximal situation of their education or focused on the professional future further away and particularly on job characteristics. Especially in the first interview students reported whether they had chosen this study focusing on a future job. A considerable group indicated the future job as being the main reason for their educational choice (i.e., I did not look at the contents of the study, only at the future jobs). Furthermore, students frequently reported about the driving forces behind their choice, their specific motives why they chose this study. Some students based their study choice purely on interest in legal topics and the contents of the study. Others were also interested in legal topics but for the sake of the later profession (i.e., I want to learn about Law because I want to become a layer, or I like to learn about legal and social topics because there are a lot of possibilities in work later on). For a third group the contents of their goals seemed to be defined by feelings of obligation or pressure (i.e., Actually I wanted to start a job but since I could not find one, I started this $s t u d y)$. Based on the different motives behind the educational choice reported in the interviews, we distinguished between intrinsic motivation, extrinsic autonomous motivation, and extrinsic controlled motivation. These three categories are based on studies making a distinction between autonomous forms of motivation and controlled forms of motivation $[5,6]$.

Finally, a third issue that emerged in almost all interviews was the attitude of students towards the study of their choice. Students reported about their expectations and attitudes to make this particular choice. Some students talked about the attractive and positive characteristics of the study of their choice and were very positive about what they expected to learn in their studies or what they expected to become later on. Others seemed to make a choice based on negative argumentation: the other options had more disadvantages (i.e., I did not want a study containing maths). A third group showed a doubtful attitude about their study choice (i.e., I don't know if I am I able to persist in this study, or Do I make the right choice of study?).

The interview data showed that many students seem to have made a choice with the intention to continue their studies after one year at university to get the Master of Law degree (LL.M), because they hope to get a legal robed profession. The Dutch educational system offers the possibility of following a sequence of studies with an increasing level (a Dutch university of applied sciences (higher professional education) prepares for a Bachelor degree of applied sciences; a Dutch university prepares for a Bachelor degree and after that for a Master degree, necessary for a legal robed profession). However, in this group the focus on the robed professions seems very frequent and salient, and this finding led us to analyze the group with an intention to continue at the 
university in more detail. We defined this phenomenon as "perspective to switch to university."

Based on our findings of the explorative-qualitative research, we made the following qualifications. The classification of time perspectives resulted in two categories: shortterm time perspective and long-term time perspective. The criteria used for the coding were the following:

(i) Participants were coded with a short-term (ST) time perspective if, in the discussion of educational choice, [s] he focused on the here and now of the studies: the attractiveness and contents of the topics and the education.

(ii) Participants were coded with a long-term (LT) time perspective if the participant, in the discussion of educational choice, focused on a future professional career and on possible jobs opportunities after education. In the School of Law, students typically focused on the so-called legal robed professions such as lawyer and judge.

Interrater agreement was 91\%, after discussion, adjustment of the coding directions, and a second round of coding.

We distinguished between three categories of utterances concerning motivation: intrinsic, extrinsic autonomous, and extrinsic controlled utterances. The criteria used for the coding were the following:

(i) Participants' utterances were coded "intrinsic" if they described their study choice as a goal in itself; the motivation to learn legal topics was a motivation that came from within.

(ii) Participants' utterances were coded "extrinsic autonomous" if they explained their study choice as based on material or other rewards, thus as an external goal, but when they also expressed volition and free choice.

(iii) Participants' utterances were coded "extrinsic controlled" if they explained their study choice as based on material of other rewards, thus as an external goal, and they expressed a sense of pressure or obligation. These participants expressed no genuine interest in the studies.

Interrater agreement was $100 \%$, after discussion, adjustment of the coding directions and a second round of coding.

For attitude we distinguished between a positive, a negative and an ambivalent attitude. The criteria used for the coding were the following:

(i) Participants were coded with a positive attitude when he or she expressed confidence and optimism with regard to his or her choice, the contents and characteristics of the studies, and the personal experience of the studies.

(ii) Participants were coded with a negative attitude when (s)he described the choice for the study in negative terms: it was second choice or the choice was based on negative arguments or the choice was motivated by lack of other options. (iii) Participants were coded with an ambivalent attitude when doubt was expressed with regard to the choice of study or their capacity to succeed in this study. A part of the codes was independently rated by the first and the second author.

The interrater reliability of attitude was computed by calculating the rate of agreement, corrected for chance. After discussion and adjustment of the coding directions the two coders agreed upon the codes for eight out of ten interviews. The disagreements were found to be based on subtleties that could not be caught by sharpening of the code directions.

2.2.1. Classification of Respondents Based on the Results of the Explorative-Qualitative Research. Participants were classified into six various groups according to the preparation they followed (or did not follow) for preparing the study choice. Each group contained approximately 15 students. The participants prepared themselves before making their educational choice in different ways. We classified these preparatory programs in two ways: a differentiated and a more global way. We did so because, for some analyses, the differentiated classification resulted in many very small or even empty cells. However, if possible, we used the differentiated classification, in which we distinguished six groups on the basis of the type of preparation of their educational choice.

Group LS. They are students following Law Summer School: an intensive orientation program of two weeks.

Group FE. They are students who switched to the Law School in the winter semester, so-called February students, who generally have followed a course in another higher education study during first semester.

Group $M H$. It is Mbo-Hbo trajectory: two days especially for graduates from senior secondary vocational education (MBO).

Group OR. It is orientation: different short orientations such as open day, "a student for one day," or a combination.

Group PK. Prior knowledge: they are students who did not prepare by organized activities but their knowledge is based on previous studies (at a lower level or at a different university).

Group WO. Without: students started without any official, organized preparation.

These groups were not completely mutually exclusive. In case they could be classified in more than one group, they were classified in the group with the most intensive preparation.

The global classification distinguished four groups, in which participants were classified with regard to the intensity of the preparation. We formed three preparation groups: "no preparation" (group WO of the differentiated classification), "preparation of some days" (MH and OR), and "preparation of two weeks" (LS). A fourth group is "former experience" (PK), and this group consisted of participants who did not 
follow a formal preparation but who had knowledge of the studies because they did comparable lower level studies before. Participants classified as FE group belonged to PK group if their previous study was also law-oriented and to WO if their previous study was not law-oriented.

2.3. Conclusion Explorative-Qualitative Research. The concepts time perspective, motivation, and attitude have been found relevant on the basis of what students reported in the interviews. Apparently these themes are important in the process of educational choice. Time perspective was categorized in two classifications: short-term time perspective and long-term time perspective. We distinguished between three motivational categories with regard to the utterances about educational choice: intrinsically motivated, extrinsically autonomously motivated, and extrinsically controlled motivated categories. For the concept attitude, we distinguished between the categories positive, negative, and doubtful. For all codes intercoder reliability was satisfying. In the next section, we will discuss literature on career counseling theories and research on (vocational) identity development in which these three concepts are related to career choice processes.

\section{Quantitative Empirical Study: The Relation between Time Perspective, Motivation, Attitude, and Study Success}

Time Perspective. Several authors define Future Time Perspective Theory (FTPT) as the extent to which one considers the future important. In principle, the term of FTPT itself (always) refers to the future, but a distinction has been made between a focus on goals in the near future or the future further ahead [7, 8]. Simons et al. [9] distinguish between short-term (ST) time perspective and long-term (LT) time perspective. In both career choice and motivation and in identity theories the concept of time perspective has been examined in relation to concepts that are expected to be relevant for study progress, such as intrinsic motivation $[10$, 11 .

Time Perspective and Motivation. Future time perspective plays a role as a motivational source: differences in time perspective-goals for the distant or far future-do have motivational effects. In studies investigating someone's motivation to achieve (future) goals and ambitions, a distinction has been made between autonomous forms of motivationintrinsic and extrinsic autonomous-and controlled forms of motivation-extrinsic controlled $[5,6,9]$. These studies are rooted in the self-determination theory (SDT) of Deci and Ryan $[10,11]$. In line with Deci and Ryan $[10,11]$ these studies distinguish three types of motivation. Besides internal motivation, a motivation that comes from within, Vansteenkiste et al. [5] distinguish extrinsic controlled motivation from extrinsic autonomous motivation. Extrinsic controlled motivation occurs when behaviors are executed with a sense of pressure or obligation, whereas extrinsic autonomous motivation refers to behaviors executed with an external goal but also involves the experience of volition and choice. In case of extrinsic autonomous motivation, learning outcomes can be just as good as goals based on intrinsic motivation $[10,11]$.

Time Perspective, Motivation, and Performance. Several studies demonstrated a relation between time perspective, motivation, and performance. Vansteenkiste et al. [12] investigated whether the contents of a goal-with intrinsic or extrinsic value-plus the context in which this goal is formulatedautonomously or controlled-affect (physical) performances. Providing a future intrinsic goal in an autonomy supported way was found to have positive effects on these performances. De Bilde et al. [13] report, again through the lens of SDT, a positive relation between an extended future time perspective and effective self-regulating learning. Based on these studies summarized above $[12,13]$, demonstrating that having an extended future time perspective is associated with enhanced motivation and better performance and that (long) future time perspectives are positively related to autonomous forms of motivation, we can presume that an extended or long future time perspective is positively related to better learning outcomes. Thus, having or developing a future oriented perspective may be expected to relate to less dropout.

However, identity theories as discussed by Bosma and Kunnen [14], based on the concept "concerns" stemming from Frijda's emotion theory [15], suggest another relation between time perspective and educational success. Concerns are defined as the driving force behind the behavior of people. Concerns thus refer to their goals. Bosma and Kunnen [14] and Frijda [15] state that proximal concerns are stronger motivators than distal concerns, concerns and goals far away in time as being less "urgent" and motivating. From this perspective, a proximal concern, such as choosing an interesting and satisfying study, fits in the short-term time perspective, whereas a distal concern, that is, the image of the future far ahead, fits in the long-term time perspective.

From the perspective of Frijda's emotion theory [15] it may be expected that an attitude that is characterized by positive feelings, expectations, and perceptions resembles a positive concern and is thus a stronger motivator than an attitude that is characterized by more negative perceptions, expectations, and feelings. Research has shown that high expectations are a better condition for study success compared to low expectations. [1, 16] Concerning a doubtful attitude, Germeijs et al. [17] report about the role of indecisiveness and high school students' career decision-making process. In general, students with doubts benefit more from guidelines to structure information instead of providing them with more, other information $[17,18]$.

Thus, different theories predict a different relation between time perspective and motivation and different implications for educational success. Because of this seeming contradiction, the complexity of the different concepts, and the lack of empirical knowledge about their relations, we chose to investigate the relation between time perspective and educational success in an open, explorative way. Furthermore, we formulated hypotheses based on the literature concerning the relation between study success and motivation and attitude. We expect that there is a positive relation between 
TABLE 1: Difference in time perspective between persisters and dropouts $(n=73)$.

\begin{tabular}{|c|c|c|c|}
\hline \multirow{2}{*}{ Study success } & \multicolumn{2}{|c|}{ Time perspective } & \multirow[b]{2}{*}{$n$ total } \\
\hline & Short-term & Long-term & \\
\hline Persisters & $34(68 \%)$ & $16(32 \%)$ & $50(100 \%)$ \\
\hline Dropouts & $4(17 \%)$ & $19(83 \%)$ & $23(100 \%)$ \\
\hline \multirow[t]{2}{*}{ Total } & 38 & 35 & 73 \\
\hline & Value & $\mathrm{df}$ & Asymp. Sig. (2-sided) \\
\hline Pearson Chi-square & 16.167 & 1 & 0.00 \\
\hline
\end{tabular}

autonomous forms of motivation and study success, and we expect to associate a positive attitude with study success. A special question will be addressed to the phenomenon that we defined as "ambition to switch to university."

\subsection{Research Questions Quantitative Empirical Studies}

An Empirical Study of the Relation between Time Perspective, Motivation, Attitude, and Study Success

\section{Research Questions}

(1) Open Questions

(3) What is the relation between time perspective and educational success, in terms of persistence or dropout?

(4) What is the role of the phenomenon defined as "perspective to switch to university"?

\section{(2) Hypotheses}

(1) We expect that autonomous forms of motivation are related to better learning outcomes.

(2) We expect that a positive attitude is related to better learning outcomes.

\subsection{Operationalization}

Study Success. Educational success was operationalized by classifying the participants into two categories: persisters and dropouts. Persisters were students who successfully finished their first year-meaning with a minimum of 50 credit points - and continued their studies at the same school or continued in a juridical track at the university, if they obtained 60 credit points. Dropouts were students who quit the law studies, either because of own choice or because of being forced, because of low achievements. Note that success is operationalized not from the retention perspective of the school but from the persistence perspective of the student. Switching to the university means "a loss" for the school but may reflect a successful continuation of one's personal educational career. Some students switched within the first year from law to Social Legal Services or vice versa. This means that these switchers were classified as persisters if they successfully continued education following the switch or as dropouts when they dropped out after they made a switch.
3.3. Analyses. We used Chi-square analysis to test the relation between study success, on the one hand, and time perspective, motivation, and attitude on the other hand. In addition, to test the significance of the differences between each of the categories in case we had too many small or empty cells, we used resampling (Monte Carlo) techniques. These techniques are particularly suited for small and unevenly distributed samples. Resampling techniques start from the assumption that differences between two categories or groups are the consequence of a random distribution. As a next step we tested, by repeated shuffling of the data, how often the empirically found difference between two categories or groups is found by random reshuffling. $p$ represents the percentage of outcomes from the random shuffling in which the same or a bigger difference was found. We then returned to the interview contents to gain more insight into the qualitative aspects of the different categories and relations.

\subsection{Results}

3.4.1. Time Perspective and Study Success (Question 3). Table 1 shows the relation between time perspective and study success.

Table 1 shows a significant relationship between time perspective and educational success $(p<0.01)$. In these analyses, 73 students were included as sixteen students could not be classified with regard to their time perspective. The majority of continuing students had a short-term time perspective, while almost all dropouts had a long-term time perspective.

Table 2 shows examples of utterances in which a person discussed his or her educational choice, which are classified as short-term and long-term future time perspective. The code at the end of each utterance indicates the type of preparation of the participant.

In the short-term (ST) utterances, the future was clearly not perceived relevant. Even if it was mentioned, for example, quote 5 of participant OR6, the future perspective did not contribute to the study choice. We see that when interest in law topics was mentioned, the quotes remained very global. Common terms are "interesting" or "I like it." The longterm utterances mainly mentioned future jobs like becoming a judge or a lawyer. Interesting is that those jobs cannot be achieved by studying law at a school for higher professional education; to reach those goals, students have to switch to the university (A Dutch university of applied sciences (higher professional education) prepares for a Bachelor degree of applied sciences; a Dutch university prepares for a Bachelor 
TABLE 2: Quotes about time perspective in the higher education choice process.

\begin{tabular}{|c|c|c|}
\hline $\begin{array}{l}\text { Time } \\
\text { perspective }\end{array}$ & Interview & Quotes \\
\hline ST & 2 & $\begin{array}{l}\text { (1) "With regard to choosing Social Legal Services (SLS) it is important to me that I } \\
\text { feel at ease and that I like the subjects" (OR9) }\end{array}$ \\
\hline ST & 1 & $\begin{array}{l}\text { (2) "I then started looking around and reading about it. I also went to an open day } \\
\text { here. The information was very clear, I knew exactly what subjects I would get, they } \\
\text { discussed everything elaborately" (FE10) }\end{array}$ \\
\hline ST & 2 & $\begin{array}{l}\text { (3) "I really like the contents of the education. I like all subjects. I thought that I } \\
\text { wouldn't like economics and tax law at all. Now that I've finished it, I think it is } \\
\text { really interesting" (MH29) }\end{array}$ \\
\hline ST & 1 & $\begin{array}{l}\text { (4) "I actually like all of it. Because I really love law, I think it’s just really } \\
\text { interesting" (PK48) }\end{array}$ \\
\hline ST & 2 & $\begin{array}{l}\text { (5) "I like the study Social Legal Services, but I don't like the possible future } \\
\text { professions" (OR6) }\end{array}$ \\
\hline \multirow{3}{*}{ LT } & 1 & $\begin{array}{l}\text { (6) "Within Law, I like it that there is a diverse range of subjects... I want to go to } \\
\text { university...I want to practice law later on. I want to continue my study at the } \\
\text { university" (1LS11) }\end{array}$ \\
\hline & 2 & $\begin{array}{l}\text { (7) "I think it's important that the subjects focus on the later profession. In law I can } \\
\text { see what the future is, it's clear which direction you're heading, what the professions } \\
\text { are. With my previous education, IBL (international business \& languages), this was } \\
\text { a bit ambiguous. You had to study subjects, IBL and didn't study to g et a certain } \\
\text { profession. That was not the case, but now it is" } \\
\text { (8) "In terms of future, I mustn't expect to pass every subject. I am not motivated to } \\
\text { swot for ambiguous subjects" (1LS11) }\end{array}$ \\
\hline & 3 & $\begin{array}{l}\text { (9) "I quitted because of the job perspective and the image that I got of the later } \\
\text { profession. I didn't want to end up in a boring office" (1LS11) }\end{array}$ \\
\hline LT & 2 & $\begin{array}{l}\text { (10) "I never looked at Law contents-wise, rather I looked at what I could become } \\
\text { later on" (MH13) }\end{array}$ \\
\hline LT & 1 & (11) "I mostly like the future job. I want to be a lawyer or a judge"...(OR1) \\
\hline LT & 1 & $\begin{array}{l}\text { (12) "I looked at the end goals. What can I achieve later on? And do I want to } \\
\text { achieve this" (PK11) }\end{array}$ \\
\hline LT & 2 & $\begin{array}{l}\text { (13) "Yes I chose SLS only because of the later profession. I already liked the } \\
\text { overview of subjects with Law better during the first interview. Perhaps it's a } \\
\text { challenge to get better results for these subjects" (PK14) }\end{array}$ \\
\hline LT & 1 & $\begin{array}{l}\text { (14) "It's because of my uncle. He is a lawyer. So he inspired me to study Law" } \\
\text { (PK29) }\end{array}$ \\
\hline LT & 1 & $\begin{array}{l}\text { (15) "My stepfather is an injury expert. I really like that profession. Then he said: if } \\
\text { you study Law you will head into the same direction of my current profession" } \\
\text { (OR10) }\end{array}$ \\
\hline LT & 2 & $\begin{array}{l}\text { (16) (question about talking about Law, with people in your environment) “....always } \\
\text { with my father and mother. They want it the most that I go the university. Or at least } \\
\text { that I anticipate on how to do this in the fastest and best way that I can. This } \\
\text { weekend my father was completely shocked when he heard about the new } \\
\text { legislation" " (PK21) }\end{array}$ \\
\hline
\end{tabular}

${ }^{*}$ After the first year you can no longer go automatically to university, without conditions.

degree and after that for a Master degree, necessary for a legal robed profession.). Several long-term quotes reflected an almost blind choice for these studies; the goal of students with a long-term time perspective was to continue their studies at the general university. In the next section, we will come back to this "University Study Perspective." In some longterm quotes we clearly see that important others played a role in the educational choice (quotes 14,15 , and 16). In quote 6 it is demonstrated that the time perspective may change over time: this person started with a rather short-term time perspective but changed to a long-term time perspective in later interviews. This long-term time perspective resulted in a decision to quit the studies.

3.4.2. Ambition Switching to the University and Study Success (Question 4). We decided to explore the frequently reported perspective to switch to the university and analyzed whether this intention is related to the educational success. As a first step we applied a Chi-square analysis to test whether there were significant relations, and next we analyzed the 
TABLE 3: The relation between study success and the intention to switch to the university $(n=89)$.

\begin{tabular}{|c|c|c|c|}
\hline \multirow{2}{*}{ Study success } & \multicolumn{2}{|c|}{ University Study Perspective } & \multirow[b]{2}{*}{$n$ total } \\
\hline & No ambition & Ambition & \\
\hline Persisters & $38(59 \%)$ & $26(41 \%)$ & $64(100 \%)$ \\
\hline Dropouts & $17(68 \%)$ & $8(32 \%)$ & $25(100 \%)$ \\
\hline \multirow[t]{2}{*}{ Total } & 55 & 34 & 89 \\
\hline & Value & df & Asymp. Sig. (2-sided) \\
\hline Pearson Chi-square & 0.566 & 1 & 0.452 \\
\hline
\end{tabular}

TABLE 4: Examples of quotes expressing the intention to switch to the university, with references to the status and to long existing dreams.

\begin{tabular}{ll}
\hline Prestige of the occupation/social status & Future dream \\
\hline $\begin{array}{l}\text { (about the profession/the future) "That you have to do } \\
\text { preparatory work for someone else. Whereas I want to } \\
\text { be the one who signs the papers..." (2LS2-P 3) }\end{array}$ & $\begin{array}{l}\text { "When I was in the last class of primary education I } \\
\text { already thought: it would be nice to become a judge or a } \\
\text { lawyer later on" (MH9-P3) }\end{array}$ \\
\hline & "I have known for a very long time that this is what I \\
"But then I was 'just a paralegal' during my internship, I \\
was only allowed to do simple things" (PK51-P1) \\
$\begin{array}{ll}\text { "I chose Law because I had wanted this for a very long } \\
\text { time, how does law work" (1LS-P20) }\end{array}$ \\
$\begin{array}{l}\text { "I already work at a law firm.... They're not kind, and } \\
\text { they look down on you" (FE6-P2) }\end{array}$ & $\begin{array}{l}\text { "I've wanted to do this for a very long time. I've wanted } \\
\text { this since the first year of secondary school. So I'm } \\
\text { really proud" (FE7-P1) }\end{array}$ \\
\hline
\end{tabular}

${ }^{*}$ A legal robed profession.

TABLE 5: The relation between type of motivation and study success.

\begin{tabular}{lccc}
\hline Study success & \multicolumn{1}{c}{ Motivation } & Extrinsic controlled & $n$ total \\
\hline Persisters & Intrinsic & Extrinsic autonomous & $6(0.0 \%)$ \\
Dropouts & $45(87 \%)$ & $19(61.0 \%)$ & $6(100 \%)$ \\
Total & $7(13 \%)$ & $12(39 \%)$ & $6(100 \%)$ \\
\hline & $52(100 \%)$ & $31(100 \%)$ & 89 \\
\hline Resampling Average and significance & Value & Df & Asymp. Sig. (1-sided) \\
\hline
\end{tabular}

interviews to get a better understanding of the intention to continue the studies at university. Table 3 shows the relation between study success and intention to switch to the university.

With regard to the intention to switch to the university, there was no significant difference between persisters and dropouts. Also, during the interviews, the intention to continue at university was often mentioned. Sometimes it was described as a long existing dream for the future; other students described this intention in relation to the higher status of the jobs that can be reached by having a university degree. Some students found out that their dream jobs were not within reach during their present studies at higher professional education. Table 4 shows examples of quotes concerning the intention to switch to the university, with references both to the status and to the long existing dreams.

3.4.3. Motivation and Study Success (Hypothesis 1). Table 5 shows that intrinsic motivation occurred mostly among persisters. Extrinsic motivation did not necessarily turn out to be a dysfunctional motivation. More than half of the students who were extrinsically autonomously motivated were persisters, while all students who were extrinsically controlled motivated were dropouts. These results were significant.

Because we did not meet the Chi-square requirements concerning cell size and because we wanted to test each pair of categories separately, we did additional analyses using resampling techniques. We assessed the chance that the differences between the three categories were caused by random distribution. Persisters got value 0 , dropouts got value 1 , and we computed the average value (thus the rate between persisters and dropouts) for each motivation category. Outcomes that differed significantly $(p<0.01)$ from each other were marked by the same letter. Thus, for example, intrinsic and extrinsic autonomous are both marked with $a$ and they differ significantly from each other. Thus persisters as compared to dropouts gave intrinsic motivations more often than either extrinsic autonomous or extrinsic controlled motivations for their choice and extrinsic autonomous motivations more often than extrinsic controlled motivations. 
TABLE 6: Examples of quotes representative for different forms of motivation.

\begin{tabular}{|c|c|c|}
\hline Motivation & Persister/dropout & \\
\hline IN & Persister & $\begin{array}{l}\text { "To me it seems like a very nice education. It seems interesting to me. } \\
\text { Just that, learning about Law" (SM25) }\end{array}$ \\
\hline IN & Persister & $\begin{array}{l}\text { "I think the social part is important in an education. That is the } \\
\text { reason why I chose Social Legal Services. I like all subjects, especially } \\
\text { "an introduction to law", but also the social subjects" (MH23) }\end{array}$ \\
\hline IN & Persister & $\begin{array}{l}\text { "I like to figure out, explore things. That seems interesting to me" } \\
\text { (2JS13) }\end{array}$ \\
\hline EA & Persister & $\begin{array}{l}\text { "I used to want to become a lawyer, because I really liked this. And I } \\
\text { watched interesting series and so on. Then my mother said; why not } \\
\text { studying Law? Then I thought this was a good idea" (SZ45) }\end{array}$ \\
\hline EA & Persister & $\begin{array}{l}\text { "At first I wanted to do something arty, like the film academy. Then I } \\
\text { realized I did not want to choose a study without any job possibilities. } \\
\text { In that case, I prefer a job at the office which interests me. I spoke } \\
\text { about it with my mother, who is a judge" (SZ13) }\end{array}$ \\
\hline EA & Persister & $\begin{array}{l}\text { "First I wanted to study psychology of applied sciences, but this was } \\
\text { all the way in Amsterdam. I chose not to do this, too far away. Finding } \\
\text { a place to live in Amsterdam can be very difficult. Then I visited the } \\
\text { open days of the Law School for Applied Sciences and I thought: this } \\
\text { really appeals to me" (2JS1) }\end{array}$ \\
\hline EC & Dropout & $\begin{array}{l}\text { "I live together now with my boyfriend, so I'm looking at the future. } \\
\text { My boyfriend is older than I am, and we want children. So, I should } \\
\text { finish the first year first, and then quit, so we can have a child. I } \\
\text { should also see whether I'm able to succeed at all, and see whether it's } \\
\text { not too hard" (FE5) }\end{array}$ \\
\hline EC & Dropout & $\begin{array}{l}\text { "In the first place, I chose the school. After that, the education. I } \\
\text { prefer a large school with a lot of windows over a little one with only } \\
\text { one floor or so. Because, yes, I have claustrophobia, so I feel safer over } \\
\text { here than in another school" (SV47) }\end{array}$ \\
\hline EC & Dropout & $\begin{array}{l}\text { "In the beginning I did not want to continue my studies, I wanted to } \\
\text { work. I had bad experiences with the organization at my former } \\
\text { school. Then my mother said: you don't know what it's going to be like } \\
\text { at a new school, maybe it's different, you are so young, why not } \\
\text { continue studying. ... I did not visit open days because I did not want } \\
\text { to continue my studies. I first needed to change my mindset" (SV14) }\end{array}$ \\
\hline
\end{tabular}

TABLE 7: Differences in attitude between persisters and dropouts $(n=78)$.

\begin{tabular}{|c|c|c|c|c|}
\hline \multirow{2}{*}{ Study success } & \multicolumn{3}{|c|}{ Attitude } & \multirow[b]{2}{*}{$n$ total } \\
\hline & Positive & Negative & Doubt & \\
\hline Persisters & $46(82 \%)$ & $7(58 \%)$ & $3(30 \%)$ & 56 \\
\hline Dropouts & $10(18 \%)$ & $5(42 \%)$ & $7(70 \%)$ & 22 \\
\hline \multirow[t]{2}{*}{ Total } & $56(100 \%)$ & $12(100 \%)$ & $10(100 \%)$ & 78 \\
\hline & Value & & $\mathrm{df}$ & Asymp. Sig. (1-sided) \\
\hline Pearson Chi-square & 12.661 & & 2 & 0.001 \\
\hline
\end{tabular}

Table 6 shows utterances consolidating the results of the Chi-square analysis. These quotes are examples of the classifications intrinsic (IN) motivation, extrinsic autonomous (EA) motivation, and extrinsic controlled (EC) motivation.

3.4.4. Attitude and Study Success (Hypothesis 2). In these analyses 78 students were included as eleven students could not be classified with regard to their attitude. Table 7 shows that continuing students had a positive attitude more often than dropouts. In addition, while a slight majority of the students with a negative attitude continued, more than half of the students with an ambivalent attitude dropped out.

To gain more insight into these outcomes we analyzed the quotes in the interviews that underlie the positive, negative, and ambivalent attitudes. These quotes, at the end of Table 7 , show two types of ambivalence: students who doubted whether they made the right choice and students who doubted whether they could successfully finish their studies. Table 8 shows these quotes. 
TABLE 8: Quotes that are illustrative for different attitudes.

\begin{tabular}{|c|c|c|}
\hline Attitude & $\begin{array}{c}\text { Persister or } \\
\text { dropout }\end{array}$ & Quote \\
\hline Positive & Persister & $\begin{array}{l}\text { (1) (about law at the university of applied sciences) "There is a lot to learn, which is } \\
\text { tough, but I've always been good at it, for example with History. So I can do that" } \\
\text { (OR1) }\end{array}$ \\
\hline Positive & Persister & $\begin{array}{l}\text { (2) "I'm definitely motivated, if I set my mind to something, I really go for it. I will } \\
\text { keep going until I understand. I want to understand what I'm studying" (FE7) }\end{array}$ \\
\hline Positive & Persister & $\begin{array}{l}\text { (3) "I actually expected the education to be much more difficult. Law, that will be } \\
\text { something. . But they really start from scratch." "I didn't have any prior knowledge } \\
\text { but I think I'm managing just fine. I have to do a lot of homework and I make a lot } \\
\text { of summaries" (MH23) }\end{array}$ \\
\hline Negative & Dropout & $\begin{array}{l}\text { (4) "I had already finished my study for half a year so I wanted to get a job, but I } \\
\text { couldn't find one" } \\
\text { "Or really, I just wanted something else. First I wanted to be nurse, but I couldn't } \\
\text { start that education until September so I didn't do that" (FE6) }\end{array}$ \\
\hline Negative & Persister & $\begin{array}{l}\text { (5) "No. I also did a test. The results always said something wit Law or Defence, So I } \\
\text { wanted to join the Air Force. But I didn't pass the test so I immediately knew what } \\
\text { to do: apply here and study Law" (WO12) }\end{array}$ \\
\hline Negative & Persister & $\begin{array}{l}\text { (6) “...But that wasn't possible because I hadn't taken Maths in secondary school. } \\
\text { And Law was actually my second choice. So I went for it, because it seemed like the } \\
\text { best thing to do besides Psychology" (OR28) }\end{array}$ \\
\hline Negative & Persister & $\begin{array}{l}\text { (7) “... I didn't really like Economics, I also looked into that. I'm not really good at } \\
\text { Maths. } \\
\text { I like the social part, but I already did that during my MBO study. So I chose the } \\
\text { business side. Thanks to my MBO-internship I'd already acquired some social } \\
\text { skills...” (MH13) }\end{array}$ \\
\hline Negative & Dropout & $\begin{array}{l}\text { (8) "Actually I wanted to go to the Willem de Koning Academy (School of Arts), but } \\
\text { my mother did not like this" (SV27) }\end{array}$ \\
\hline Doubting & Dropout & $\begin{array}{l}\text { (9) "After the secondary vocational education I was not sure I wanted to follow this } \\
\text { education. I was doubting. It's all confusing" (MH9) }\end{array}$ \\
\hline Doubting & Persister & $\begin{array}{l}\text { (10) "I have dyslexia.... I spoke to someone at the open day who reassured me, he } \\
\text { also had dyslexia...I did not subscribe because I was uncertain. I wanted to wait till } \\
\text { this conversation..." (OR4) }\end{array}$ \\
\hline Doubting & Dropout & $\begin{array}{l}\text { (11) "I'm dreading it, I don't have any legal background, and I followed a secondary } \\
\text { vocational education. They also warned us over there; higher vocational education } \\
\text { is not easy" (MH17) }\end{array}$ \\
\hline Doubting & Dropout & $\begin{array}{l}\text { (12) "I applied for Social Legal Services, but I'm not entirely sure yet. } \\
\text { At vocational education I did not choose for Personnel Work, because you have to } \\
\text { work a lot with people. So I choose Business Services. That's why I now doubt if this } \\
\text { is the right profession for me." "If I pass all my resits this period, I'm fine with it. But } \\
\text { if I fail the social subjects again, I will start doubting. . . Now I am doubting if I have } \\
\text { made the right choice" (PK14) }\end{array}$ \\
\hline Doubting & Dropout & $\begin{array}{l}\text { (13) (about the moment of applying for a study) “...because I was vacillating } \\
\text { between Social Legal Services and Law. July, August, yes I think it was August that I } \\
\text { applied. I also applied for Social Work because I was still making up my mind. Yes, I } \\
\text { put a lot of thought into it, because I had to make a choice. What am I going to do: } \\
\text { Social Work or Social Legal Services" (WO30) }\end{array}$ \\
\hline
\end{tabular}

3.5. Relation between Time Perspective, Motivation, Attitude and Educational Success. Students with a long-term time perspective were found to drop out more often (question 3).

Nevertheless, no difference was found between the intention to switch to the university and study success (question 4). We found that educational success is positively related to intrinsic and extrinsic autonomous motivation; hypothesis 1 was confirmed. Furthermore, extrinsic controlled motivation only occurred among the dropouts. Not surprisingly, we found a strong positive relation between choosing a study out of a positive attitude and continuation of the study; hypothesis 2 was confirmed. More than half of the students who started with an ambivalent attitude became a dropout. Furthermore, the quotes suggest that the quality of the ambivalence may differ between persisters and dropouts. Some students - quotes 10, 11 and 12 - doubted their capacities 
TABLE 9: The relation between time perspective and intensity of preparation $(n=73)$.

\begin{tabular}{|c|c|c|c|}
\hline \multirow{2}{*}{ Intensity of preparation } & \multicolumn{2}{|c|}{ Time Perspective } & \multirow[b]{2}{*}{$n$ total } \\
\hline & Short-term time perspective & Long-term time perspective & \\
\hline Two weeks & $14(78 \%)$ & $4(22 \%)$ & $18(100 \%)$ \\
\hline Some days & $14(61 \%)$ & $9(39 \%)$ & $23(100 \%)$ \\
\hline Former experience & $7(47 \%)$ & $8(53 \%)$ & $15(100 \%)$ \\
\hline No preparation & $3(18 \%)$ & $14(82 \%)$ & $17(100 \%)$ \\
\hline \multirow[t]{2}{*}{ Total } & 38 & 35 & 73 \\
\hline & Value & Df & Sign. (2-sided) \\
\hline Resampling average level of preparation & 2.02 & 1.09 & 0.014 \\
\hline
\end{tabular}

to succeed in their studies, while others -quotes 13 and 14doubted the rightness of their choice, and whether or not the study fitted them well.

\section{An Empirical Study of Preparation Programs and Orientation Activities}

In this third section we investigated how the intensity of preparation before making an educational choice is related to the time perspective. Furthermore, we explored whether there was relation between the ambition to switch to the university and the intensity of the preparation before the start of the study. Finally, we examined the relation between these different types of preparation that were followed by the students, and their study success.

Study preparation programs may help prospect students to make them aware of proximal topics such as the contents of subjects, but also offer a realistic image of the more distal issues such as the professional context or the future profession. In the interviews students discussed the information they had about the studies, and the exploration process prior to the choice. Students develop their image of a study during the process of making an educational choice. Because of the high dropout rates, universities offer students elaborate orientation activities and intensive programs to support students in this process. Inholland University of Applied Sciences offers different types of orientation activities and preparatory programs. In previous studies it was found that students who attend an organized preparation often are more successful in their studies than students who do not attend such a preparation, and they start their studies with a more realistic image [2, 19]. Germeijs and Verschueren [20] investigated the exploratory behavior of adolescents choosing a study in higher education. Their study distinguished between six different steps in the career decision- making process, that is, choice actualization, academic adjustment, commitment to the chosen study. They provided evidence for the importance of orientation and broad exploration at the beginning of the career decision-making process, whereas in-depth exploration and decisional status are considered important later on [20]. Kunnen emphasized in her research of these differents steps, that effective guidance trajectories should focus on personal development, and the importance of considering educational choice as one step in a longer process [18].

\subsection{Research Questions}

(5) Do students with more intensive preparation have another time perspective than students with less preparation?

(6) Is there a relationship between the ambition to switch to the university and the type of preparation program or orientation activities that student followed? We addressed these two questions as open questions. Furthermore, based on the research discussed above, we hypothesize that more intensive preparation is positively related to study success.

Hypothesis 3. We expect that the more intensive the preparation, the higher the chance of study success.

\subsection{Results}

4.2.1. Time Perspective and Preparation for Educational Choice (Question 5). Table 9 shows the relation between time perspective and the type of preparation. For this analysis we used the more global classification of types. The focus of our analysis was on the knowledge the students had about their studies. Based on their intensity, we formed three preparation groups ranging from "no preparation" to "preparation of two weeks”. A fourth group consisted of participants who did not follow a formal preparation, but who had knowledge of the studies because they did a comparable lower level studies before. In these analyses, 73 students were included as sixteen students could not be classified with regard to their time perspective.

A significant difference between the preparation groups was found. The group with the most intensive preparation most often had a short-term time perspective, while the group who started their studies without any preparation or knowledge at all often had a long-term time perspective. Again, in Table 9, we did not meet the Chi-square requirements concerning cell size. Just as for Table 5, we did additional analyses using resampling techniques. We rank ordered the different forms of preparations by intensity, by giving numbers to the different types: from 0 for No Preparation to 3 for Two Weeks. We computed the average value rank ordered scores for short-term and long-term perspective. For this analysis we assessed the chance that differences in scores between both time perspectives were caused by random factors. Differences 
TABLE 10: The relation between the intention to switch to the university and the types of preparation $(n=89)$.

\begin{tabular}{|c|c|c|c|}
\hline \multirow{2}{*}{ Preparation $^{1}$} & \multicolumn{2}{|c|}{ University Study Perspective } & \multirow[b]{2}{*}{$n$ total } \\
\hline & No ambition & Ambition & \\
\hline LS & $8(40 \%)$ & $12(60 \%)$ & $20(100 \%)$ \\
\hline FE & $8(73 \%)$ & $3(27 \%)$ & $11(100 \%)$ \\
\hline $\mathrm{MH}$ & $11(100 \%)$ & $0(0 \%)$ & $11(100 \%)$ \\
\hline OR & $10(53 \%)$ & $9(47 \%)$ & $19(100 \%)$ \\
\hline PK & $9(69 \%)$ & $4(31 \%)$ & $13(100 \%)$ \\
\hline WO & $9(60 \%)$ & $6(40 \%)$ & $15(100 \%)$ \\
\hline \multirow[t]{2}{*}{ Total } & 55 & 34 & 89 \\
\hline & Value & $\mathrm{df}$ & Asymp. Sig. (2-sided) \\
\hline Pearson Chi-square & 12.383 & 5 & 0.03 \\
\hline \multicolumn{4}{|c|}{ 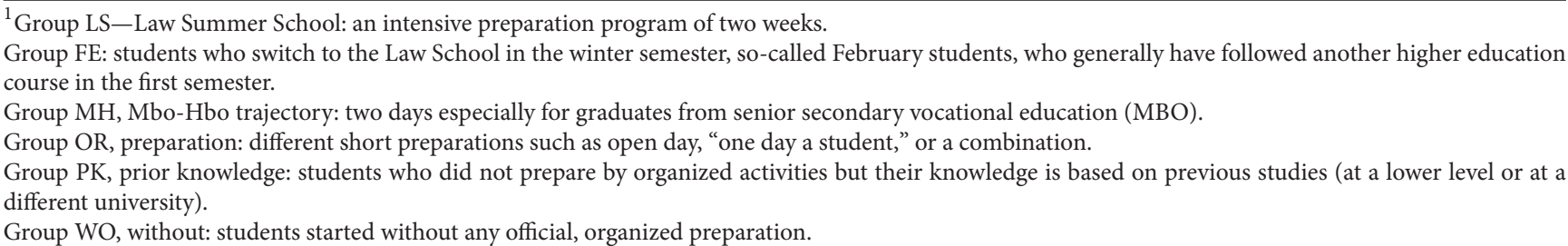 } \\
\hline
\end{tabular}

between long-term and short-term perspective were found to be significant $(p<0.001)$.

\subsubsection{Ambition to Switch to the University and Preparation} for Educational Choice (Question 6). For the analysis of the intention to continue at university and the different types of preparation before choosing the studies, it was possible to choose for the more differentiated classification, given the cell sizes. Table 10 shows the relation between the intention to switch to the university and the types of preparation. The differences between the types of preparation are significant, but this significance should be considered with caution, because one of the cells is empty.

The Law Summer School (LS) group contained a majority of students who aimed to continue at university, and no students from the Preparation for Secondary Vocational Education graduates, meaning group $(\mathrm{MH})$, showed that intention. This result is a bit surprising when we relate it to our earlier findings above, which stated that a long-term time perspective is related to dropout chances. In the previous section we found out that dropouts predominantly have a long-term time perspective, while the ambition to continue at university does not differentiate between students who continue or dropout. However, when we consider the group with the most intensive preparation, the Summer School group, we see that this group shows the intention to continue at university most frequently, and at the same time, often have a short-term time perspective. This seems counterintuitive. How can these students choose a study while focusing on the here and now, the proximate focus, and at the same time intend to continue at university, which sounds like a long-term time perspective? To get a better understanding of this discrepancy, we analyzed the interviews in detail. Table 11 shows that many students started their studies with a short-term time perspective in the first interview, so before they had started their studies, and during the year, thus in the second and third interview, they developed a long-term time perspective and started to focus on the possibility of continuing the law study at university.

These quotes suggest that the intention to switch to the university in the groups with an intensive preparation, the Law Summer School (LS codes) group and also the Short Preparation, group OR, developed throughout the year. The quotes of the dropouts from groups with less preparation show that their intention to go to university was already mentioned in the first interview, but seemed to be almost "blind", without arguments or knowledge about the studies.

4.2.3. Preparation before the Choice and Study Success (Hypothesis 3). We investigated the relationship between educational success and preparation, and we used the more global classification in four groups. Table 12 shows the relation between study success following different preparatory programs of different intensity. We explored the relation with Chi-square as a one sided test of significance.

We found a significant $(p<0.05)$ difference in chance of success between preparatory programs of different intensity. Almost all students with a two-week preparation continued successfully and most dropouts were found in the groups with no preparation, or former experience only. This confirms our hypothesis that more intensive preparation is related to less chance of dropout.

4.2.4. Preparation Programs and Orientation Activities. We found that participants who followed a more intensive form of preparation more often gave reasons for their choice that could be classified as short-term time perspective (question 5).

We found significant differences concerning the intention to continue at university in the preparation groups: the Summer School group had the intention to continue at university somewhat more often than the other groups (question 6). The interviews gave a more detailed view, revealing that especially 
TABLE 11: Quotes that illustrate the developing ambition throughout the academic year to switch to the university versus participants wishing to switch to the university from the very beginning of the academic year.

\begin{tabular}{lcll}
\hline Persister/dropout & Interv & Time Persp & $\begin{array}{l}\text { Quote regarding stepping over to university after one } \\
\text { year }\end{array}$ \\
\hline Persister & 3 & ST & $\begin{array}{l}\text { (1) "It's not that I don't like it anymore, but I did all I } \\
\text { could, I can now try going to university, so why not" } \\
\text { (1LS6) }\end{array}$ \\
\hline Persister & 3 & ST & $\begin{array}{l}\text { (2) "If I pass all tests of year 1 and finish the first year I } \\
\text { will definitely go to university (Law school). I know } \\
\text { what I'm about to start, if you don't try you'll never } \\
\text { know. I've asked multiple people about the university } \\
\text { study" (1LS4) }\end{array}$ \\
\hline
\end{tabular}
study" (1LS4)

(3)"I do want to finish the first year. I already applied to
the university. It was never my plan. But I now found

$\begin{array}{lll}\text { Persister } & 3 & \text { ST }\end{array}$
out that this is really the way for me and I started doubting the path I was on. Someone suggested this to me, so I've already applied" (1LS2)

(4) (talking about education) "with the girls from my class. I mean, one wants to go to university and the other just wants to finish the professional bachelor course and then go to university. The other thinks: I'm fine where I am right now and I don't know about the rest. ..I'm not so sure about it. Because, of course, going to university... what if, you don't make it, then you have to go back!" (OR22)

$\begin{array}{ll}\text { Persister } & \text { ST }\end{array}$

ST (5) "I'm not sure if I had already decided this during our previous interview, but I have now decided to go to the university. At least, that's what I want to do. And I think it's important that I have a good basis before I get there. Because I'm actually doing quite well. And not just because of that. Because I originally just wanted to do my professional bachelor" (OR22)

(6) "I just think it's a really great study. I think it's interesting. . Just that you're studying law." "And I want

$\begin{array}{lll}\text { Persister } & 1 & \text { ST }\end{array}$
to try to get my propaedeutic. Not because I then want to go to university. But I would then at least have the opportunity to go" (OR25)

\begin{tabular}{|c|c|c|c|}
\hline Dropout & 1 & LT & $\begin{array}{l}\text { (7) "I know for sure that I want to go to university and } \\
\text { become a lawyer. I want to specialise in criminal law" } \\
\text { (OR24) }\end{array}$ \\
\hline Dropout & 1 & LT & $\begin{array}{l}\text { (8) "What I want the most is finishing the first year and } \\
\text { go to university. Because my friends are there as well..." } \\
\text { (WO35) }\end{array}$ \\
\hline Dropout & 1 & LT & $\begin{array}{l}\text { (9) (about the parents) "They think Law (of applied } \\
\text { sciences) is alright, but they rather see me going to } \\
\text { university. So I'm going to try finishing the first year" } \\
\text { (OR46) }\end{array}$ \\
\hline Dropout & 1 & LT & $\begin{array}{l}\text { (10) "My goal is to get my Propedeuse in the first year, } \\
\text { and then go to university. I actually didn't look at other } \\
\text { options. My goal is to pursue a Law degree" (LL.M) }\end{array}$ \\
\hline
\end{tabular}

the Law Summer School (LS) and the Short Preparation (OR) groups seemed to develop their university ambition throughout the year. They started with a focus on proximal characteristics such as the contents of the study, and gradually developed a longer-term time perspective throughout the year, in which they formulated the intention to continue their studies at university. The intention to continue at university in the other groups seemed to be a more abstract view of a future far ahead. The interviews were very clear at this point; in almost all interviews this was a general theme, except from the group with graduates from senior secondary vocational education (The complete data set (in Dutch) is available on demand, please contact the corresponding author.).

The hypothesis concerning the relation between the type of preparation is also confirmed: the groups with the most 
TABLE 12: Study success following different preparatory programs of different intensity $(n=89)$.

\begin{tabular}{|c|c|c|c|c|c|}
\hline \multirow{2}{*}{ Study success } & \multicolumn{4}{|c|}{ Preparation } & \multirow[b]{2}{*}{$n$ total } \\
\hline & Two-week & Some days & Former experience & No preparation & \\
\hline Persisters & $18(90 \%)$ & $22(76 \%)$ & $12(63 \%)$ & $12(63 \%)$ & 64 \\
\hline Dropouts & $2(10 \%)$ & $7(24 \%)$ & $9(37 \%)$ & $7(37 \%)$ & 25 \\
\hline \multirow[t]{2}{*}{ Total } & $20(100 \%)$ & $29(100 \%)$ & $21(100 \%)$ & $19(100 \%)$ & 89 \\
\hline & Value & & df & & Asymp. Sig. (1-sided) \\
\hline Pearson Chi-square & 6.452 & & 3 & & 0.046 \\
\hline
\end{tabular}

intensive preparation activity drop out less frequently than those without preparation.

\section{General Conclusions and Discussion}

Our findings concerning time perspective and the students' motivation and attitudes towards and preparation on their studies provide some insight into the way in which these concepts relate to study success in the first year. Students with a long-term time perspective were defined as students who based their choice on later job possibilities; students with a short-term time perspective focused on the contents and characteristics of the studies. Dropouts were found to be almost always students with a long-term time perspective. Dropouts seemed to be ambitious at the beginning, because they often indicated that they aimed to continue their education at university. Our results, especially the quotes of these students, suggest that their choice may not be well-informed. Some students were categorized with "ambition to switch to university"; they had a rather abstract idea, sometimes based upon a long existing dream for the future, of both the university and the legal robed professions that they aimed for.

In line with the initial findings on motivation $[5,6,10$, 11] we found a positive relation between the two forms of autonomous motivation with positive learning outcomes, while studying out of external pressure was associated with negative study outcomes. Our findings confirmed that persisters are characterized by intrinsic or extrinsic autonomous motivation, whereas extrinsic controlled motivation occurred only among dropouts.

Furthermore, utterances of the students in this study showed that having an extended future time perspective is associated with a strong drive. This finding is in line with the studies discussed in the theoretical framework $[9,13]$. Interviews showed that a lot of students studying law were oriented towards a future far ahead and, besides that, they were very driven to achieve the ultimate profession: lawyer or judge. On the other hand, we could not relate more perseverance or optimal learning outcomes to an extended future time perspective, since our findings related an extended orientation to the future to dropout. This finding is, surprisingly, compared to the studies mentioned above $[12,13]$ but in line with the earlier description of concerns in publications of Bosma and Kunnen and Frijda. They state that distal goals, far ahead in the future, are less motivating than proximal goals $[14,15]$.

All in all, we recapitulate our results of the relation between study success on the one hand and future time perspective and motivation on the other hand as follows. Extrinsic autonomous motivation can be just as meaningful as intrinsic motivation when it comes to persistence. In the interviews students with an extended future time perspective showed a strong drive, but no evidence was found for the relation between long-term future time perspective and more study success. Students who followed a two-week Summer School as preparation (the LS group) made their choice based on the characteristics of the study. During the first year they developed an intention to continue their law studies at university, and this emerging long-term time perspective is not related to dropout.

Not surprisingly, students' attitudes regarding educational choice were especially positive for students who successfully continued their education. Less expected is that more than $50 \%$ of students who started their studies with a "negative" attitude still continued successfully. A more surprising finding is that an ambivalent attitude turns out to be related to dropout more strongly than a "negative" attitude. Apparently a second choice or a choice based on the least unattractive option (those where the criteria for a negative attitude) can result in a positive educational success, while that happens less in case of doubt. Our findings showed that students who showed doubt have the highest risk to dropout. In the interviews quotes we distinguished between doubt based on uncertainty about one's own competence and doubt based on uncertainty about whether one has made the right choice of study. These findings are in line with the research of Germeijs et al. who showed that indecisiveness forms a risk factor for coping with career decisional tasks [17].

Students who followed more intensive types of preparation gave short-term reasons for their choice more often. An explanation for this finding may be that in the preparation they were provided with detailed information about the study. Although this should be tested in additional research, it is possible that, for students who found this information attractive, it became an important reason for their choice, while students who found the information not attractive may have decided to choose another study.

Our hypothesis that more intensive preparation before making an educational choice would be related to study success was confirmed. The group with the most intensive preparation showed the least dropout. The group of students who did not follow any preparation showed the highest dropout levels. The "prior knowledge" group did not follow any organized preparation, but these students had knowledge of the studies based on previous experience. This is a more 
complicated and probably vulnerable group. On the one hand, they did follow some type of law education, so they had some knowledge of these types of studies. On the other hand, either these students dropped out because of their previous similar level law studies at another institute or they followed a more vocational and less difficult law related study.

Our findings are relevant for the educational institutions. First of all, they suggest that intensive preparation programs may help students to start their studies with a more complete image and with more realistic expectations. Secondly, we found that a too strong focus on later jobs, before but also after the start of the studies, may not be optimal. This seems to be counterintuitive for institutions of higher professional education, considering that they are offering programs which are primarily practice oriented. Nonetheless, for career choice preparation programs, it seems to be more important to focus on the characteristics of the studies, and it is less desirable to attract students with descriptions of specific later jobs. Educational programs should adapt the vocational part of their curriculum to a focus on professional context or job related tasks instead of a focus on the "job itself." Finally, institutions should pay special attention to students characterized by indecisiveness and doubts. Although more evidence is needed to ensure whether the risk for dropout with such students is valid for other groups as well, this finding may be relevant for the guidance of first-year students, not only during their intake sessions but also during their coaching programs. Personal coaching in order to address doubts may strengthen the students' trust in their choice and foster their educational success.

We should be careful, however, with the generalization of these findings to studies and students in general. This study focused on students of one specific educational trajectory in one city in Netherlands. In some of our analyses we found very strong and convincing relations, for example, the finding that almost all dropouts had a long-term perspective. Our research shows that the distinction between a shortterm future time perspective and a long-term future time perspective is too vague. There are extended future time perspectives that are not realistic and not made on the basis of the contents of the studies. On the other hand, there are longterm future time perspectives that are developed throughout the first year, rooted in knowledge about the contents of the studies and their possibilities. These results have implications for future research: one should consider the precise goals and the target group before associating an extended future time perspective and success.

Relevant processes and factors (such as the focus on legal robed professions) in this study may be very specific for this specific type of education. We think that one of the lessons of this study can be that if we want to understand what really happens in educational choice and the later educational success and dropout, we should focus on one specific group in detail, instead of trying to find a broad and general sample in which all specific processes disappear in the average numbers. In that way, we may grasp the processes, instead of finding relations that are statistically significant but explain only a small part of the variance and that are not really helpful in designing career choice projects and educational guidance.
Naturally, a collection of such specific studies may help us to gain insight into general processes and mechanisms and to draw general conclusions for present and future career choice information and guidance, as well as for the organization of higher professional education.

\section{Competing Interests}

The authors declare that there are no competing interests regarding the publication of this paper.

\section{References}

[1] V. Tinto, Completing College, Rethinking Institutional Action, The University of Chicago Press, Chicago, Ill, USA, 2012.

[2] J. Warps and Onderzoek LOB en Studiesucces, Onderzoek Naar de Opbrengst van LOB op Basis van de Startmonitor 2012-2013 in Opdracht van de VO-Raad, Researchned Nijmegen, 2013.

[3] B. Glaser and A. Strauss, The Discovery of Grounded Theory: Strategies for Qualitative Research, Hawthorne, New York, NY, USA, 1967.

[4] H. A. Bosma, E. S. Kunnen, and M. A. E. van der Gaag, Groninger Identity Development Scale Revised 2011, Rijksuniversiteit Groningen, Groningen, The Netherlands, 2011.

[5] M. Vansteenkiste, J. Simons, W. Lens, and B. Soenens, "De kwaliteit van motivatie telt: over het promoten van intrinsieke doelen op een autonomie ondersteunende wijze," Nederlands Tijdschrift voor de Psychologie, vol. 59, pp. 119-131, 2004.

[6] M. Vansteenkiste, E. Sierens, B. Soenens, K. Luyckx, and W. Lens, "Motivational profiles from a self-determination perspective: the quality of motivation matters," Journal of Educational Psychology, vol. 101, no. 3, pp. 671-688, 2009.

[7] J. Simons, S. Dewitte, and W. Lens, "Wanting to have vs. wanting to be: the effect of perceived instrumentality on goal orientation," British Journal of Psychology, vol. 91, no. 3, pp. 335-351, 2000.

[8] J. Nuttin and W. Lens, Future Time Perspective and Motivation: Theory and Research Method, Erlbaum, Hillsdale, NJ, USA, 1985.

[9] J. Simons, M. Vansteenkiste, W. Lens, and M. Lacante, "Placing motivation and future time perspective theory in a temporal perspective," Educational Psychology Review, vol. 16, no. 2, pp. 121-139, 2004.

[10] E. L. Deci and R. M. Ryan, “The 'what' and 'why' of goal pursuits: human needs and the self-determination of behavior," Psychological Inquiry, vol. 11, no. 4, pp. 227-268, 2000.

[11] E. Deci and R. Ryan, Intrinsic Motivation and Self-determination in Human Behavior, Plenum, New York, NY, USA, 1985.

[12] M. Vansteenkiste, J. Simons, B. Soenens, and W. Lens, "How to become a persevering exerciser? Providing a clear, future intrinsic goal in an autonomy-supportive way," Journal of Sport \& Exercise Psychology, vol. 26, no. 2, pp. 232-249, 2004.

[13] J. De Bilde, M. Vansteenkiste, and W. Lens, "Understanding the association between future time perspective and self-regulated learning through the lens of self-determination theory," Learning and Instruction, vol. 21, no. 3, pp. 332-344, 2011.

[14] H. A. Bosma and E. S. Kunnen, "Determinants and mechanisms in ego identity development: a review and synthesis," Developmental Review, vol. 21, no. 1, pp. 39-66, 2001.

[15] N. Frijda, De Emoties. Een Overzicht van Onderzoek en Theorie, Bert Bakker, Amsterdam, The Netherlands, 2005. 
[16] C. H. Van Onzenoort, Als Uitval Opvalt. Studie-Uitval in het Hoger Beroepsonderwijs, Proefschrift UvA, Amsterdam, The Netherlands, 2010.

[17] V. Germeijs, K. Verschueren, and B. Soenens, "Indecisiveness and high school students' career decision-making process: longitudinal associations and the mediational role of anxiety," Journal of Counseling Psychology, vol. 53, no. 4, pp. 397-410, 2006.

[18] E. S. Kunnen, Studiekeuze en Studiekeuzebegeleiding Vanuit een Ontwikkelingspsychologisch Gezichtspunt, Kluwer Navigator Onderwijs, Module Leerlingenzorg VO, Kluwer, Alphen aan den Rijn, The Netherlands, 2013.

[19] W. Lens, "Succesfactoren in het studiekeuzeproces; motivatie en keuzebegeleiding," Nieuwskrant KU Leuven, vol. 11, no. 6, 2000.

[20] V. Germeijs and K. Verschueren, "De keuze van een studie in het hoger onderwijs: het beslissingsproces, risicofactoren, en de samenhang met de uitvoering van de keuze," Caleidoscoop, vol. 19, no. 2, p. 2, 2007. 


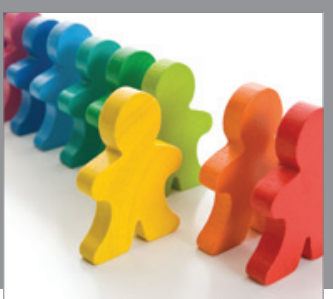

Autism

Research and Treatment
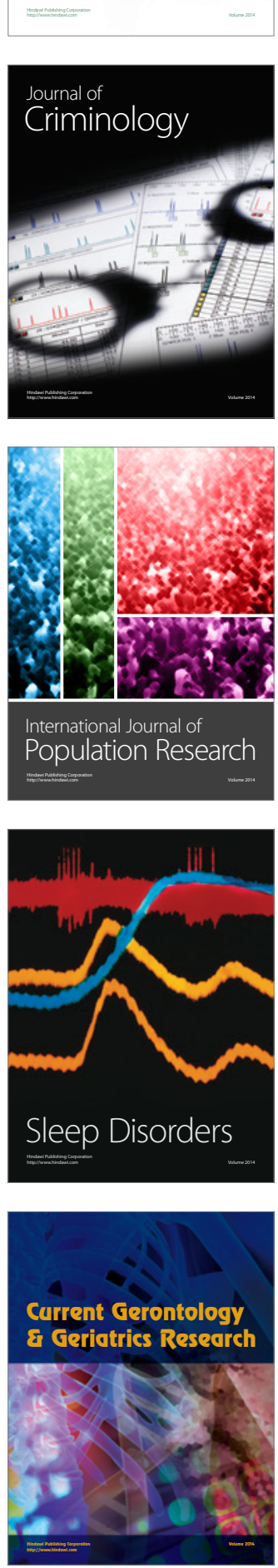

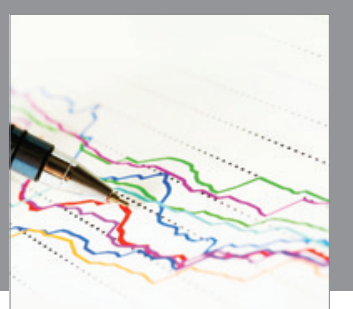

Economics

Research International
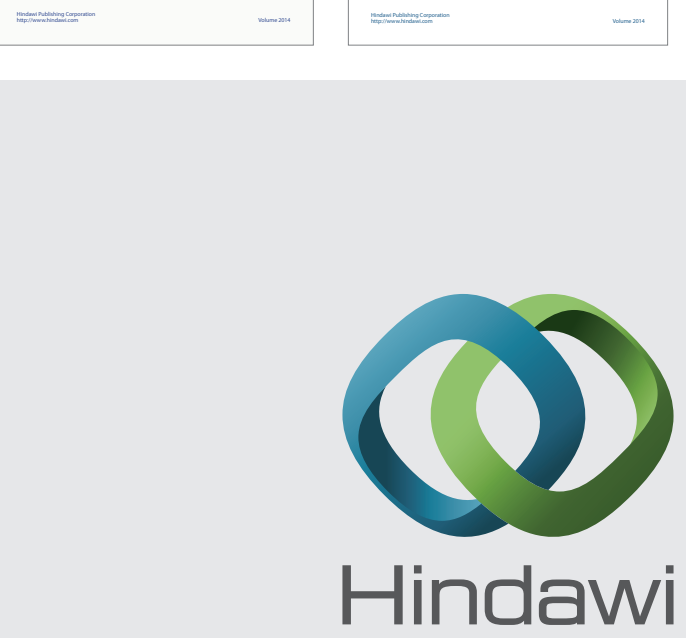

Submit your manuscripts at

http://www.hindawi.com
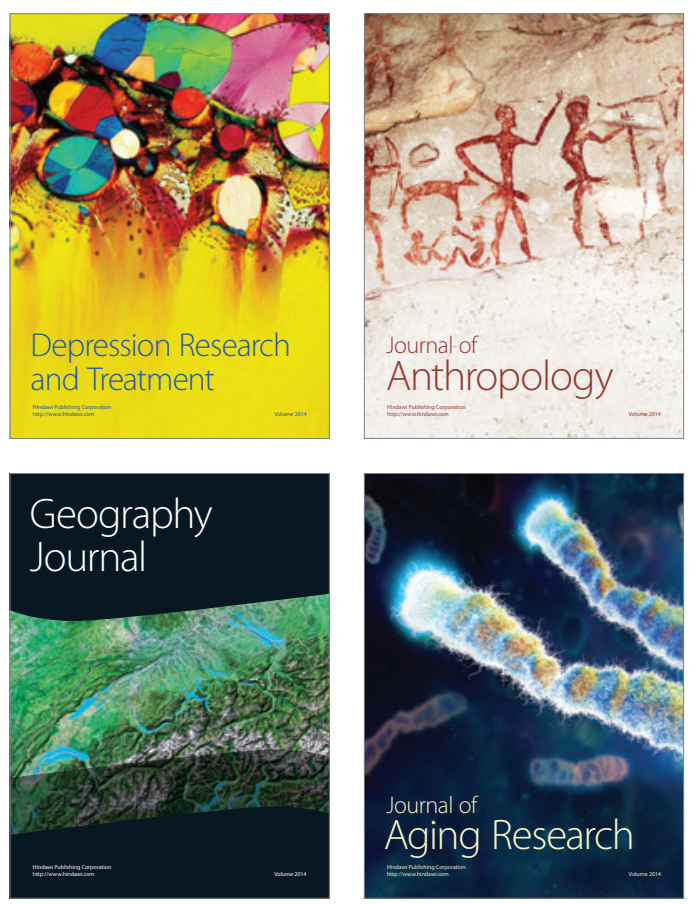
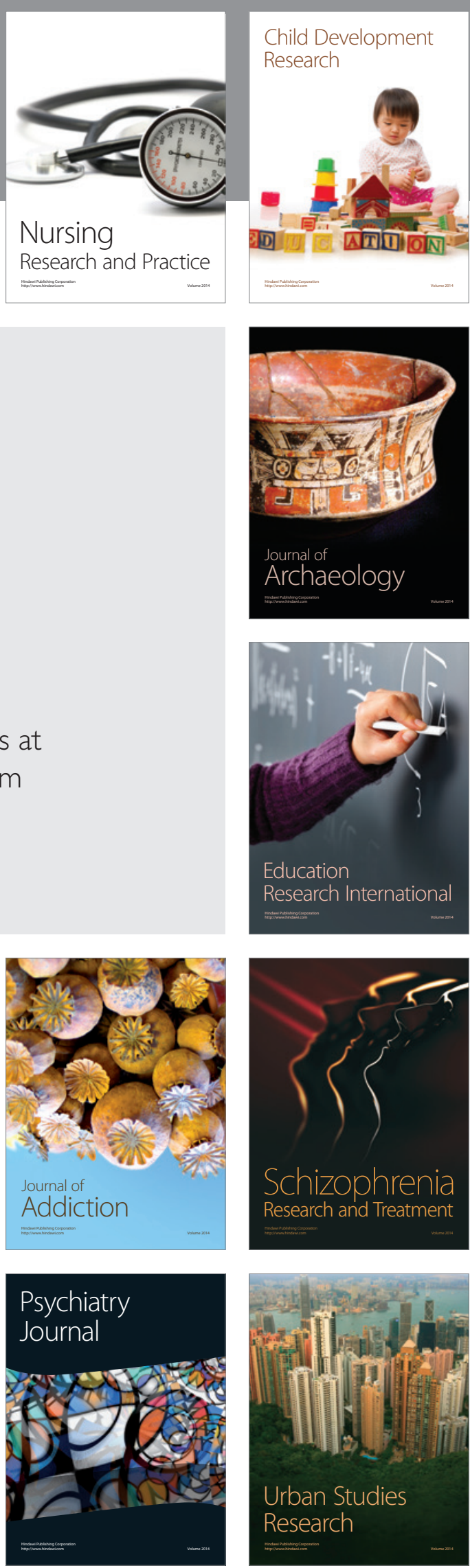